\title{
EFFECTS OF NANO MINERAL-SUPPLEMENTED DIET ON SOW PRODUCTIVITY
}

\author{
Hoang Nghia Son ${ }^{1}$ \\ Animal Biotechnology Department, Institute of Tropical Biology, VAST, Vietnam \\ Received 25 October 2019, accepted 20 December 2019
}

\begin{abstract}
This study aimed to evaluate the effects of nano mineral-supplemented diet on sow productivity. The data were estimated by several parameters consisting of piglet live ratio at newborn stage and weaning stage, piglet weight at newborn stage and weaning stage, metal content in piglet livers. The results showed that live ratio of newborn piglets in group III was highest $(93.44 \pm$ $2.83 \%$ ) comparing with other groups. However, there was no significant difference of live ratio in piglets at weaning stage between nano mineral-supplemented groups with control. The birth weight of piglets in nano mineral-supplemented groups was similar to control group. The birth weight of piglets in nano mineral-supplemented groups was ranged from 1,361.61 \pm 47.37 grams (group II) to $1,410.48 \pm 44.28$ grams (group I). However, the average weight of weaned pigs in groups III and IV was higher than other groups $(6,772.92 \pm 105.47$ grams and 6,818.87 \pm 89.59 grams). Moreover, the amount of $\mathrm{Fe}, \mathrm{Cu}, \mathrm{Zn}, \mathrm{Mn}$ in piglet liver from nano mineral-supplemented groups have been found to be lower than those in control group. These results revealed that the supplement of nano minerals for sows promoted the reproductive performance of sows and reduced mineral content in the liver of piglets.
\end{abstract}

Keywords: Birth weight, nano mineral, piglets, sow productivity.

Citation: Hoang Nghia Son, 2019. Effects of nano mineral-supplemented diet on sow productivity. Academia Journal of Biology, 41(4): 111-115. https://doi.org/10.15625/2615-9023/v41n4.14692.

Corresponding author email: hoangnghiason@yahoo.com

(C2019 Vietnam Academy of Science and Technology (VAST) 


\section{INTRODUCTION}

Minerals play important roles in the growth and development of cattle and poultry, especially in pig farming. Minerals are widely used in agriculture, crops and livestock, but they only have a positive effect with suitable dosage. Minerals contribute to cell structure, participate in cell functions, maintaining the development of teeth, bones and muscles as well as supporting to functions of the nervous system (Teixeira et al., 2016; Gerlinger et al., 2019). Minerals are substances that the body cannot produce, they should be provided through diet and digestion. A good diet with supplemented minerals will contribute to growth, development and production of pigs (Raje et al., 2018). The abusing of micronutrients in large amounts is not only beneficial to pig health, but also increases production costs and badly impact to the environment (Gaudré \& Quiniou, 2009). Thus, nano mineral production is considered to be one of the best methods to control and reduce the supplemented mineral amount for pig diets. Several nano minerals have been used for pig diets, including nano $\mathrm{Zn}$, nano $\mathrm{Cr}$, nano $\mathrm{Cu}, \mathrm{Fe}$, Se (Yang et al., 2006; Bunglavan, 2013, Gonzales-Eguia et al.,, 2009; Wang et al., 2007). The Pig growth rate could be improved bu supplementation of 50 ppm nano $\mathrm{Cu}$ (Yang et al., 2006). Nano $\mathrm{Cr}$ could increase higher serum level of total protein HDL and lipase activity in pig treated with $200 \mu \mathrm{g}$ nano $\mathrm{Cr}$ (Gonzales-Eguia et al., 2009). The growth performance of piglets could be enhanced by supplement of nanoparticles of $\mathrm{ZnO}$, leading utility and benefits in weaned piglets (Wang et al., 2007). However, the effect off nano mineral supplementation for sow diets has not been characterized. In this study, we aimed to assess the effects nano mineral-supplemented diet on the productivity of sow.

\section{MATERIALS AND METHODS}

\section{Food preparation}

The mixture of $\mathrm{nFe}, \mathrm{nCu}, \mathrm{nZn}, \mathrm{nMn}$ and nCo powders is weighed and treated with ultrasound in the Ultrasonic machine G08
(Germany) for 30 minutes. The nSe solution consequently was dispersed mixtures. The accurately amount of additives were added to food and mixed at $200 \mathrm{rpm}$. Food was prepared in $25 \mathrm{~kg}$ bag.

\section{Animal and experimental design}

A total of 35 pregnant sows (Landrace) were used in this experiment. Pigs were kept individually in an area of $1.8 \mathrm{~m} \times 2.3 \mathrm{~m}$. Each cage is equipped with a separate feeding trough, with automatic drinking system. The experiment was designed in 5 experimental groups. The sows of control group were fed with inorganic mineral premix supplement according to the recommended requirements of NRC 1998 for sows. The sow of Group I was fed by basal diets supplemented with with $10 \mathrm{mg} / \mathrm{kg} \mathrm{nMn}, 32 \mathrm{mg} / \mathrm{kg} \mathrm{nFe}, 4 \mathrm{mg} / \mathrm{kg} \mathrm{nCu}$, $0.06 \mathrm{mg} / \mathrm{kg}$ Co, $0.06 \mathrm{mg} / \mathrm{kg} \mathrm{nSe}$, and 40 $\mathrm{mg} / \mathrm{kg} \mathrm{nZn}$. The nano mineral content used for Group II, III, and IV were 2, 4, and 8-fold higher than in Group I, respectively.

\section{Data collection}

Effects of nano mineral-supplemented diet on sow productivity was assessed by collecting parameters including the live ratio of piglet at newborn stage and weaning stage, piglet weight at newborn stage and weaning stage, metal content in piglet livers.

\section{Metal concentration measurement}

Piglet liver samples were sent to Viet Tin analysis testing company (79 Truong Dinh Street, Ben Thanh Ward, District 1, Ho Chi Minh City) to determine metal concentration. The metal content analysis was accredited VILAS (ISO/IEC 17025:2005).

\section{Piglet weight measurement}

The newborn piglets were put in box weighed by electronic weighing machine. Piglets at weaning stage were kept in cage and weighed by electronic weighing machine.

\section{Statistical Analysis}

All experimental data were preliminarily processed by Excel 2007. The statistical analysis was performed using one-way 
ANOVA where $\mathrm{P} \leq 0.05$ was considered statistically significant.

\section{RESULTS AND DISCUSSION}

Effect of nano mineral supplement on live ratio

The sows were fed with nano mineral supplementation and maintained during stages of mating, pregnancy and lactation. Figure 1 showed that live ratio of newborn piglets of group III was highest $(93.44 \pm 2.83 \%)(\mathrm{P}<$ $0.05)$. There was no significant difference of live ratio in piglets at newborn stage between control group and experimental groups I, II, and IV $(79.43 \pm 4.16 \%, 84.35 \pm 5.42,86.99 \pm$ $1.24 \%$, and $89.33 \pm 3.56 \%$, respectively). The live ratio of group I, II, III, IV were $80.75 \pm$ $3.78 \%, 92.33 \pm 5.81,80.92 \pm 2.48,86.57 \pm$ $4.56 \%$, respectively. There was no significant difference in live ratio in piglets at the weaning stage between control group and other groups $(88.48 \pm 4.83 \%)$.

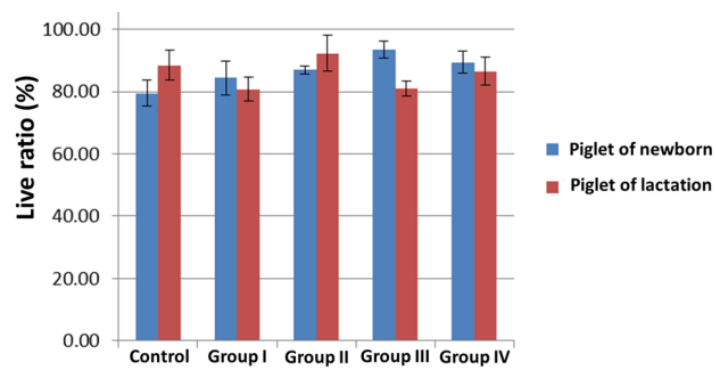

Figure 1. Effect of nano mineral supplement on piglet survival

\section{Effect of nano mineral supplement on piglet weight}

The average birth weight was the lowest in control group $(1,318.87 \pm 40.41$ grams $)$ and the highest in group I $(1,410.48 \pm 44.28$ grams) (Fig. 2). Group II, III, IV were nearly the same $(1,371.95 \pm 48.04$ grams; $1,361.61 \pm$ 47.37 grams; $1,384.52 \pm 43.44$ grams). However, the difference between these groups was not statistically significant.

The average weight of weaned pigs in groups IV was $6,818.87 \pm 89.59$ grams which was highest $(\mathrm{P}<0.01)$ (Fig. 3). The average weight of weaned pigs in groups III was
$6,772.92 \pm 105.47$ grams which was higher than group I, II, and control group $(\mathrm{P}<0.05)$. There was no significant difference between control group (6452.17 \pm 97.64 grams), group I $(6456.00 \pm 102.51$ grams $)$ and group II $(6464.86 \pm 113.25$ grams $)$.

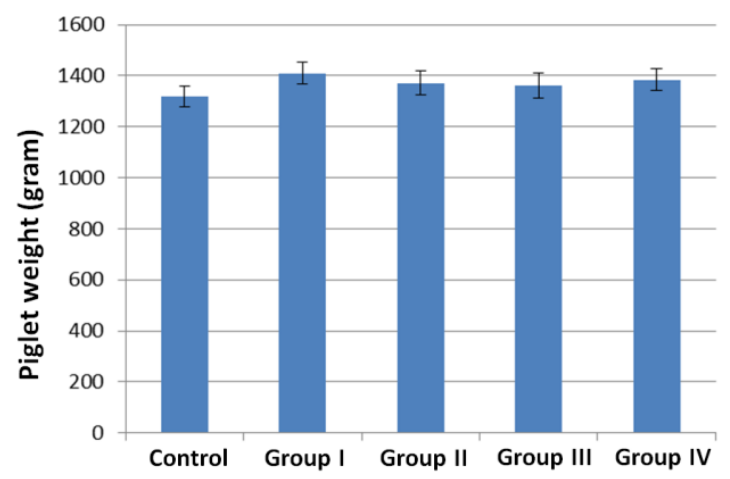

Figure 2. The average weight of newborn piglets in the experimental groups

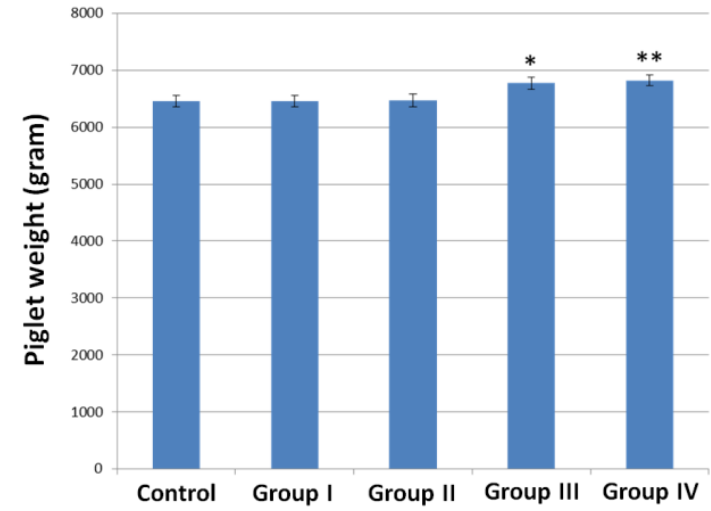

Figure 3. The average weight of weaned pigs in the experimental groups

\section{Metal concentration measurement}

The Figure 4 demonstrated that the Fe content in piglet liver of control group and group IV were $127.07 \pm 2.98 \mathrm{mg} / \mathrm{kg}$ and $112.87 \pm 8.44 \mathrm{mg} / \mathrm{kg}$, respectively, which were higher than group I, group II, group III $(\mathrm{P}<0.001)$. The $\mathrm{Fe}$ content in piglet liver of group I, group II, group III were $62.43 \pm 2.07$ $\mathrm{mg} / \mathrm{kg}, 66.90 \pm 6.09 \mathrm{mg} / \mathrm{kg}$, and $84.00 \pm 2.81$ $\mathrm{mg} / \mathrm{kg}$, respectively. There was no significant difference between group I, II, and III. The $\mathrm{Cu}$ 
content in piglet liver was highest in control group $(42.53 \pm 2.86 \mathrm{mg} / \mathrm{kg})$. There were no significant differences in $\mathrm{Cu}$ content of piglet liver among group I $(22.73 \pm 2.53 \mathrm{mg} / \mathrm{kg})$, group II $(32.07 \pm 3.80 \mathrm{mg} / \mathrm{kg})$, group III $(22.70 \pm 1.57 \mathrm{mg} / \mathrm{kg})$, and group IV $(27.27 \pm$ $0.88 \mathrm{mg} / \mathrm{kg}$ ). Similar to $\mathrm{Fe}$ and $\mathrm{Cu}, \mathrm{Zn}$ content in piglet liver in the control group was also highest $(105.53 \pm 5.72 \mathrm{mg} / \mathrm{kg})(\mathrm{P}<0.05)$, significantly higher than that in groups I, II, III, IV $(79.27 \pm 6.67 \mathrm{mg} / \mathrm{kg}, 97.93 \pm 7.50$ $\mathrm{mg} / \mathrm{kg}, 85.27 \pm 2.67 \mathrm{mg} / \mathrm{kg}, 87.73 \pm 3.88$ $\mathrm{mg} / \mathrm{kg}$, respectively). The Mn content in the piglets of the control group was the highest $(3.14 \pm 0.01 \mathrm{mg} / \mathrm{kg})(\mathrm{P}<0.01)$, significantly higher than groups I, II, III, IV $(2.40 \pm 0.15$ $\mathrm{mg} / \mathrm{kg}, 2.13 \pm 0.01 \mathrm{mg} / \mathrm{kg}, 2.37 \pm 0.04 \mathrm{mg} / \mathrm{kg}$, $2.74 \pm 0.08 \mathrm{mg} / \mathrm{kg}$ ). Group IV showed a higher Mn content in piglet liver than group I, II, and III $(\mathrm{P}<0.05)$.

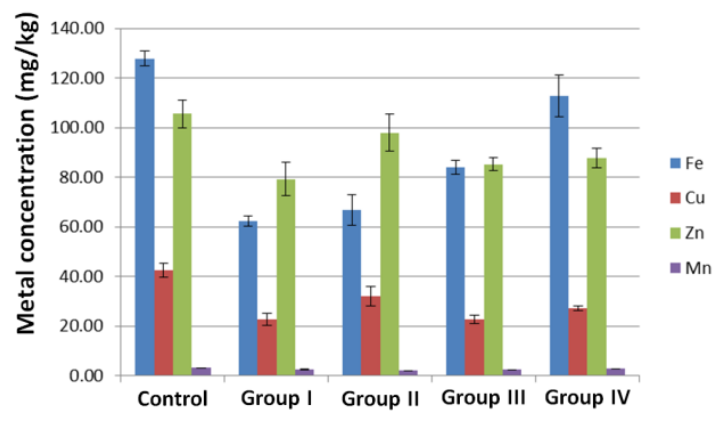

Figure 4. Metal content in the piglet's liver

The commercial pig production showed the highest percentage of mortality in the weaning stage (Roehe \& Kalm, 2000). The birth weight and mortality of piglets could be impacted by many factors during growing (Fix et al., 2010). The increased weight of piglets has been considered to decrease mortality at newborn stage and weaning stage (Lund et al., 2002). The weaned piglets with higher weight showed higher performance and quality traits after weaning (Fix et al., 2010). The highest live ratio of piglets in newborn stage was found in weighing $0.88-1.38 \mathrm{~kg}$ (Smith et al., 2007). Moreover, the piglet weighing less than 1.000 grams at newborn stage showed slower growth, less efficiency and produced a carcass with high percentage of fat and less muscle than larger pigs (Powell et al., 1980).

In this study, we found that the birth weight of piglets treated with nano minerals showed the average weight from 1,361.61 \pm 47.37 grams (group II) to $1,410.48 \pm$ 44.28 grams (group I), suggesting that the nano mineral-treated piglets got the normal weight (Smith et al., 2007). On the other hand, mineral content analysis indicated that the value of $\mathrm{Fe}, \mathrm{Cu}, \mathrm{Zn}, \mathrm{Mn}$ in piglet liver in groups I, II, III were similar and they were lower than those in the control groups and group IV. Thus, the supplement of nano minerals for sows in groups I, II, III and IV had the effect of increasing the reproductive performance of sows and reducing the amount of nano minerals in the liver of piglets. The level of nano mineral supplementation for sows in group III was the most significant and could be chosen for application in pig breeding.

\section{CONCLUSION}

The present study found the optimized content of nano mineral in supplementation of diet for the sow. Nano mineral supplementation promotes the reproductive performance of sows by increasing live ratio of newborn piglets and weight of weaned pigs.

Acknowledgments: This work was supported by Grant VAST.TD.NANO.03/15-18 from Vietnam Academy of Science and Technology.

\section{REFERENCES}

Bunglavan S. J., 2013. Effect of supplementation of selenium nano particles on growth and health status of guinea pigs. Thesis, PhD. Deemed University, Indian Veterinary Research Institute, Izatnagar, India, pp. 140.

Fix J. S., Cassady J. P., Holl J. W., Herring W. O., Culbertson M. S., See M. T., 2010. Effect of piglet birth weight on survival and quality of commercial market swine. Livest. Sci., 132: 98-106. 
Gaudré D., Quiniou N., 2009. What mineral and vitamin levels to recommend in swine diets?. R. Bras. Zootec., 38(spe): 190-200.

Gerlinger C., Oster M., Borgelt L., Reyer H., Muráni E., Ponsuksili S., Polley C., Vollmar B., Reichel M., Wolf P., Wimmers., 2019. Physiological and Transcriptional Responses in Weaned Piglets Fed Diets with Varying Phosphorus and Calcium Levels. Nutrients, 11(2): E436.

Gonzales-Eguia A., Fu C. M., Lu F. Y., Lien T. F., 2009. Effects of nanocopper on copper availability and nutrients digestibility, growth performance and serum traits of piglets. Livest. Sci., 126(1): 122-129.

Lund M. S., Puonti M., Rydhmer L., Jensen J., 2002. Relationship between litter size and perinatal and pre-weaning survival in piglets. Anim. Sci., 74: 217-222.

Powell S. E., Aberle E. D., 1980. Effetcs of birth weight on growth and carcass composition of swine. J. Anim. Sci., 50: 860-868.

Raje K., Ojha S., Mishra A., Munde V. K., Rawat C., Chaudhary S. K., 2018. Impact of supplementation of mineral nano particles on growth performance and health status of animals. A review. $J$. Entomol. Zool. Stud., 6(3): 1690-1694.

Roehe R., Kalm E., 2000. Estimation of genetic and environmental risk factors associated with pre-weaning mortality in piglets using generalized liner mixed models. Anim. Sci., 70: 227-240.

Smith A. L., Stalder K. J., Serenius T. V., Baas T. J., Mabry J. W., 2007. Effect of piglet birth weight on weights at weaning and 42 days post weaning. J. Swine Health Prod., 15: 213-218.

Teixeira A. O., Corassa A., Moreira L. M., Nogueira E. T., Lopes J. B., Rocha Junior C. M., Ferreira V. P. A., 2016. Bone characteristics of pigs fed different sources of phosphorus. Rev. Colom. Cienc. Pecua., 29(4): 245-254.

Wang M. Q., Xu Z. R., Zha L. Y., Lindemann M. D., 2007. Effects of chromium nanocomposite supplementation on blood metabolites, endocrine parameters and immune traits in finishing pigs. Anim. Feed Sci. Technol., 139:69-80

Yang Z. P., Sun L. P., 2006. Effects of nanometre $\mathrm{ZnO}$ on growth performance of early weaned piglets. Journal of Shanxi Agricultural Sciences, 3: 024. 